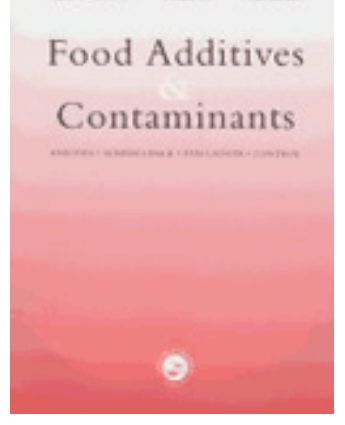

\title{
Comparison of immunohistochemical, histochemical and immunochemical methods for detection of wheat protein allergens in meat samples and cooked, dry, raw and fermented sausage samples
}

\begin{tabular}{|r|l|}
\hline Journal: & Food Additives and Contaminants \\
\hline Manuscript ID: & TFAC-2010-306.R1 \\
\hline Danuscript Type: & Original Research Paper \\
\hline Author: & O7-Mar-2011 \\
\hline Complete List of Authors: & $\begin{array}{l}\text { Lukášková, Zuzana; University of Veterinary and Pharmaceutical } \\
\text { Sciences Brno, Department of Vegetable Foodstuff and Plant } \\
\text { Production } \\
\text { Tremlová, Bohuslava } \\
\text { Pospiech, Matej } \\
\text { Renčová, Eva } \\
\text { Randulová, Zdeňka } \\
\text { Steinhauser, Ladislav } \\
\text { Reichová, Aneta } \\
\text { Bednáŕ, Josef }\end{array}$ \\
\hline Additives/Contaminants: & Allergens \\
\hline Food Types: & Cereals, Meat \\
\hline & \\
\hline Methods/Techniques: &
\end{tabular}

\section{SCHOLARONE Manuscripts}




\section{Comparison of immunohistochemical, histochemical and immunochemical}

2 methods for detection of wheat protein allergens in meat samples and

3 cooked, dry, raw and fermented sausage samples

4

Z. Řezáčová Lukášková ${ }^{1 *}$, B. Tremlová ${ }^{1}$, M. Pospiech ${ }^{1}$, E. Renčová ${ }^{2}$, Z. Randulová ${ }^{1}$, L.

6 Steinhauser ${ }^{3}$, A. Reichová ${ }^{1}$, J. Bednár ${ }^{4}$

7

$8 \quad{ }^{1}$ Department of Vegetable Foodstuff and Plant Production, Faculty of Veterinary Hygiene

9 and Ecology, University of Veterinary and Pharmaceutical Sciences Brno, Palackého 1-3,

1061242 Brno, Czech Republic

$11{ }^{2}$ Veterinary Research Institute, Brno, Czech Republic

$12{ }^{3}$ Department of Meat Hygiene and Technology, Faculty of Veterinary Hygiene and Ecology,

13 University of Veterinary and Pharmaceutical Sciences Brno, Czech Republic

$14{ }^{4}$ Department of Statistics and Optimization, Institute of Mathematics Faculty of Mechanical

15 Engineering, Brno University of Technology, Czech Republic

16

17 *Correspondence: Z. Řezáčová Lukášková. E-mail: H07310@ VFU.CZ 


\section{Abstract}

23 Nowadays is it a common practice to add vegetable protein in the production of meat 24 products. Because of the possible substitution of high quality raw meat with vegetable protein 25 without the labeling the product package and because of the allergenic potential of many 26 vegetable proteins, it is important to develop as accurate methods for its detection. The 27 objective of the present study was to compare histochemical, immunochemical (ELISA, 28 ALERT gliadin screening test), and immunohistochemical methods for detection of wheat 29 protein in meat samples and sausages. Histochemical methods were useful for detection of 30 flour in meat samples, but immunohistochemical method was better for detection of wheat 31 protein. ALERT gliadin screening test detected gliadin from $10 \mathrm{mg} \mathrm{kg}^{-1}$ while an 32 immunohistochemical method detected wheat protein concentrations from $1 \mathrm{~g} \mathrm{~kg}^{-1}$ and 33 ELISA method detected wheat protein concentrations from $4 \mathrm{~g} \mathrm{~kg}^{-1}$. ALERT gliadin 34 screening test showed results within one day, whilst an ELISA detection method took two 35 days, and an immunohistochemical procedure took 5 days at the soonest, all including sample 36 preparation. This study also focused on optimization of an immunohistochemical method for 37 samples of cooked sausage. In addition, three samples were sufficient for wheat protein 38 detection at concentration of $1 \mathrm{~g} \mathrm{~kg}^{-1}$ (and greater) with confidence level greater than $95 \%$.

40 Keywords: Food allergens, wheat proteins, gluten, gliadin, histochemistry,

41 immunochemistry, immunohistochemistry 
43

44

\section{Introduction}

During food production, various plant-origin proteins are used as additives in order to improve nutritional, flavour, and visual properties of food products (Pickering et al. 1995). However, plant proteins can be major allergens which can cause an atopic eczema (Sicherer and Sampson 1999), gastrointestinal disturbances, or other health complications in sensitive individuals (Hischenhuber et al. 2005). In production of foodstuffs of plant as well as animal origin, common allergens include wheat gluten containing gliadin and prolamin proteins. These are present also in wheat flour (Day et al. 2006) and are very important for dough, pastry and biscuits and pasta too. Gluten-containing proteins in incorrectly labeled products can have negative impact on the health of the consumers suffering from celiac disease, or gluten allergy (Ciclitira et al. 2005). The addition of plant proteins can negatively influence guaranteed storage period of some meat products, since it increases water binding capacity in foodstuffs (Vaňha et al. 2002). Plant proteins can also be used to substitute animal protein, which may cause, in case of inadequate product labeling, food adulteration (Pospiech et al. 2009).

Wheat protein (gluten), wheat flour or breadcrumb, which also contained wheat flour, are due to technological and economical reasons traditionally added to meat products (especially to cooked sausage or forcemeat) and also to vegetarian foodstuffs production. The vegetarian foodstuffs production can contain also wheat germ. In addition, wheat protein can be contained in baking powder or another thickening agents.

The development of reliable and fast methods for detection of plant-origin proteins, particularly of plant allergens, is essential (Poms et al. 2004). These requirements are met, for example, by these methods: immunochemical procedures (Moriyama et al. 2005) (radioimmunoanalysis, immunoelectrophoresis, enzymatic immunoanalytical methods ELISA) (Asensio et al. 2008; Thompson and Méndez 2008), PCR - polymerase chain 
68

69

70

reaction (Zeltner et al. 2009), but also immunohistochemical methods (Pospiech et al. 2009). Another possibility includes mass spectrometry (Šalplachta et al. 2005). Nevertheless, all these methods are not suitable for common food examination, in particular to meet the needs of the food control authorities.

The detection of allergens in food products can be very difficult, as they are often present only in trace amounts or are masked by the food matrix (Poms at al., 2004). Immunological techniques are generally very sensitive and specific and have become very popular for detection of small amounts of allergens. These methods based on the reactivity between the antigen and the antiserum recognize only particular regions of the protein with a characteristic structure called epitopes (Belloque at al., 2002). This mechanism is the same for immunohistochemical methods which we used to develop histological and high-sensitive immunological methods.

With regard to the fact that the amount of allergenic protein inducing allergic reaction shifts within a broad range of concentrations and is specific for each individual (Stern et al. 2001), an important monitored aspect is the reliability of detection of added wheat protein. The aim of this study was to compare histochemical, immunochemical, and immunohistochemical methods for detection of wheat protein in meat and sausage samples with and without additives.

\section{Materials and methods}

\section{Preparation of meat samples}

Meat samples were prepared from pork meat without additive (control) and with $10 \mathrm{~g} \mathrm{~kg}^{-1}, 2 \mathrm{~g}$ $\mathrm{kg}^{-1}, 3 \mathrm{~g} \mathrm{~kg}^{-1}, 4 \mathrm{~g} \mathrm{~kg}^{-1}, 5 \mathrm{~g} \mathrm{~kg}^{-1}, 10 \mathrm{~g} \mathrm{~kg}^{-1}, 25 \mathrm{~g} \mathrm{~kg}^{-1}$, and $50 \mathrm{~g} \mathrm{~kg}^{-1}$ of wheat protein (Amylon, a. s., Havlíčkův Brod, Czech Republic). Other meat samples were prepared from pork meat with $5 \mathrm{~g} \mathrm{~kg}^{-1}, 10 \mathrm{~g} \mathrm{~kg}^{-1}, 25 \mathrm{~g} \mathrm{~kg}^{-1}$, and $50 \mathrm{~g} \mathrm{~kg}^{-1}$ of wheat medium flour (Penam, a. s., Brno, 
93 Czech Republic). Another meat sample was prepared from pork meat with $10 \mathrm{~g} \mathrm{~kg}^{-1}$ wheat 94 protein and $10 \mathrm{~g} \mathrm{~kg}^{-1}$ wheat soft flour (Penam, a. s., Brno, Czech Republic).

95

\section{Preparation of sausage samples}

Sausage samples were manufactured based on recipes described by Šedivý (1998). The products included cooked sausage, raw sausage, dry sausage, and fermented sausage without additive (control) and with $1 \mathrm{~g} \mathrm{~kg}^{-1}, 5 \mathrm{~g} \mathrm{~kg}^{-1}, 15 \mathrm{~g} \mathrm{~kg}^{-1}$, and $30 \mathrm{~g} \mathrm{~kg}^{-1}$ of wheat protein (Amylon, a. s., Havlíčkův Brod, Czech Republic). The wheat protein was added during processing in a sausage cutter.

\section{Sample treatment and preparation}

For ELISA method and ALERT gliadin screening test, samples in size of $250 \mathrm{~g}$ were taken from each meat and sausage sample and subsequently frozen. Other samples in size of $1 \mathrm{~cm}^{3}$ were taken from meat samples. Samples in size of $1 \mathrm{~cm}^{3}$ were taken from sausage samples of cooked sausage from six locations (on either end and in the middle of the product always from the center and subsurface layer). As the seventh sample of cooked sausage, homogenate was prepared from either end and from the middle of the product by means of grinding in a blender TM 4510 type FP 2111 (Concept, Hong Kong, China). The sample in size of $1 \mathrm{~cm}^{3}$ from raw sausage, dry sausage, and fermented sausage was only taken from the center of model meat product.

The samples were processed for histological and immunohistochemical examination according to the procedure described by Pospiech et al. (2009). Samples $\left(1 \mathrm{~cm}^{3}\right)$ were fixed in $10 \%$ water solution of neutral formalin for more than 24 hours. After fixation, the samples were dewatered in ascending sequence of alcohol in the autotechnicon apparatus Leica TP1020 - Automatic Tissue Processor for Histology Applications (Leica Microsystems 
$118 \mathrm{GmbH}$, Wetzlar, Germany), and embedded into paraffin blocks in Paraplaste that were cut to

$1194 \mu \mathrm{m}$ sections at rotation microtome Leica RM2255 (Leica Microsystems GmbH, Wetzlar,

120 Germany). Model meat product samples of cooked sausage were cut into 75 sections (25

121 slides with three sections each), while always $50 \mu \mathrm{m}$ were trimmed between individual

122 sections. The sections were spread on the water surface and mounted on slides SuperFrost 123 plus (Menzel-Gläser, Menzel GmbH \& Co KG, Braunschweig, Germany).

\section{Immunohistochemical examination of samples}

126 In total 117 sections from 13 meat samples (nine sections from each sample) were processed

127 immunohistochemically. Further, 2625 sections of cooked sausage and six sections of every 128 other sausage samples were examined immunohistochemically.

129 The procedure for immunohistochemical detection of wheat protein based on avidin 130 biotin complex (ABC), derived from procedure described by Pospiech et al. (2009) was used.

131 This indirect three-stage method is more amplification method which uses high binding

132 affinity between avidin and biotin for antibodies detection. At first a polyclonal anti-wheat 133 antibody isolated from a rabbit (Sigma-Aldrich Company, St. Louis, USA) in dilution 1:1000 134 diluted with antibody diluent (DakoCytomation ref. S0809, Glostrup, Denmark) is bound to 135 an antigen. In negative control, the primary antibody was substituted by antibody diluent 136 (DakoCytomation ref. S0809, Glostrup, Denmark). In the second phase, a biotin-conjugated 137 secondary antibody (VectorLaboratories, PK 6101, Burlingtone, USA) is attached to the 138 bound primary antibody. The third stage is bond between avidin - biotin complex 139 peroxidase from the $\mathrm{ABC}$ reagent (VectorLaboratories, PK 6101, Burlingtone, USA) and 140 secondary biotinylated antibody which significantly amplifies signal.

141 The background was visualized in Calleja bath for $5 \mathrm{~min}$ or in toluidine bath for $1 \mathrm{~min}$ 142 and washed in water bath while some sections were left without background staining. Meat 
143 samples containing $10 \mathrm{~g} \mathrm{~kg}^{-1}$ wheat protein as well as $10 \mathrm{~g} \mathrm{~kg}^{-1}$ wheat soft flour were after

144 immunohistochemical detection stained by a combination of PAS - Calleja (Protocols 1997),

145 Lugol - Calleja (Protocols 1989), Lugol (Bancroft at al. 1994) - toluidine blue (Flint 1994),

146 and PAS - toluidine blue staining (Bancroft at al. 1994). Summary of all used examinations is 147 presented in Table 1.

148 PAS - Calleja staining - sections were immersed in: (1) orthoperiodic acid for 10 min,

149 (2) washed in reduction bath and then (3) in 70\% aqueous ethanol (v/v), (4) Schiff's reagent 150 for $15 \mathrm{~min}$, (5) washed in water bath for $15 \mathrm{~min}$, (6) Calleja bath for $5 \mathrm{~min}$ and washed in 151 water bath.

152 Lugol - Calleja staining - sections were immersed in: (1) Lugol bath for 5 min, (2)

153 Calleja bath for 5 min and washed in water bath.

154 Lugol - toluidine blue staining - sections were immersed in: (1) Lugol bath for 5 min, 155 (2) toluidine bath for 1 min and washed in water bath.

156 PAS - toluidine blue staining: sections were immersed in: (1) orthoperiodic acid for $15710 \mathrm{~min}$, (2) washed in reduction bath and then (3) in 70\% aqueous ethanol (v/v), (4) Schiff's 158 reagent for $15 \mathrm{~min}$, (5) washed in water bath for $15 \mathrm{~min}$, (6) toluidine bath for $1 \mathrm{~min}$ and 159 washed in water bath.

\section{Histochemical examination of samples}

162 From selected meat samples (meat with $25 \mathrm{~g} \mathrm{~kg}^{-1}$ addition of wheat protein, meat with $25 \mathrm{~g}$

$163 \mathrm{~kg}^{-1}$ addition of wheat flour), twelve sections were stained by general microscopic staining 164 (six sections hematoxylin - eosin (Bancroft at al. 1994), six sections toluidine blue (Flint 165 1994)), twelve sections by special microscopic staining (six sections Lugol - Calleja 166 (Protocols 1989), six sections PAS - Calleja (Protocols 1997)). Summary of all used 167 examinations is presented in Table 1. 
169

170

171

172

173

174

175

176

177

178

179

180

181

182

183

184

185

186

187

188

189

190

191

192

The examination procedure

After histochemical and immunohistochemical detection, the total number of 2766 sections were examined in a light microscope Nikon ECLIPSE E200 (Fuji Bldg, Tokyo, Japan) at magnification of 40x. In case of obscurities, magnifications of 100x and 400x were used. A set of digital photographs was captured to document the results by means of a digital camera Canon PowerShot G9 (Canon inc., Japan) with use of picture capturing software PSRemote Version 1.5.2 (Breeze systems, Bagshot, UK).

\section{Immunochemical examination of samples}

ELISA method

The indirect competitive ELISA was prepared according to Rencova et al. (2000) and Rencova and Tremlova (2009) and then it was modified for the detection of wheat gliadin in model meat samples. Meat samples with wheat protein were simultaneously tested for the presence of wheat proteins.

The immunization antigen was prepared from purified wheat gliadin (Sigma-Aldridge, USA). The amount of $5 \mathrm{mg}$ of gliadin was dissolved in $1 \mathrm{ml}$ of $70 \%$ ethanol $\mathrm{v} / \mathrm{v}$ with the addition of $10 \mu \mathrm{l}$ of acetic acid. This volume was adjusted to $5 \mathrm{ml}$ with the protein concentration of $1 \mathrm{mg} \mathrm{ml}^{-1}$. Three mice BALB/C of 10 weeks old and $22 \mathrm{~g}$ weight were immunized using purified gliadin antigen dissolved in 70\% ethanol mixed 1:1 with complete Freund's adjuvant (Sigma Aldridge, USA) administered subcutaneously. The antigen concentration was $50 \mu \mathrm{g} \mathrm{ml}^{-1}$ and the immunization dose was $0.1 \mathrm{ml}$. Boosters were applied twice in three weeks intervals 1:1 with Freund's incomplete adjuvant. Test sera were collected by tail bleeding 10 days after each injection; the titer of the sera was then determined by indirect ELISA. The last booster was applied intraperitoneally 4 days before the fusion. 
193 Spleen cells were fused with the myeloma cell line (P3x63.Ag8.653., ATCC CRL 1580) at a

194 ratio of 5:1 in the presence of polyethylene glycol. The next procedure was applied according 195 to Chi-Chen et al. (2001). The purified antibodies were titrated against gliadin using indirect 196 ELISA.

197 Meat samples of $20 \mathrm{~g}$ were processed in the blender with $200 \mathrm{ml}$ of $70 \%$ ethanol v/v. 198 After a 30 min extraction process, the extract solution was centrifuged at $10000 \mathrm{x} \mathrm{g}$ and $4^{\circ} \mathrm{C}$ 199 for $10 \mathrm{~min}$ and the supernatant was used for analysis.

200

\section{ALERT gliadin screening test}

202 For comparison of results achieved by the above described procedures, sausage samples were 203 examined also by ALERT gliadin screening test (Neogen corporation, Lansing, USA) 204 designed for qualitative analysis of gluten-free food products for the presence of gliadins and 205 prolamins found in wheat, barley and rye. The producer claims that the test is able to detect 206 already addition of $10 \mathrm{mg} \mathrm{kg}^{-1}$ of these allergens. ALERT test is based on principle of 207 sandwich enzyme-linked immunosorbent assay. Gliadin is first extracted from samples with a $20840 \%$ dilution of ethanol. Extract is diluted in Phosphate Buffered Saline (PBS), 80g 1-1 NaCl, $2092 \mathrm{~g} \mathrm{l}^{-1} \mathrm{KCl}, 2 \mathrm{~g} \mathrm{l}^{-1} \mathrm{KH}_{2} \mathrm{PO}_{4}, 23,4 \mathrm{~g} \mathrm{l}^{-1} \mathrm{Na}_{2} \mathrm{HPO}_{4} * 12 \mathrm{H}_{2} \mathrm{O}, 0,16 \mathrm{~g} \mathrm{l}^{-1} \mathrm{NaOH}$ adjusted to $\mathrm{pH} 7,4$, 210 and applied to antibody-coated wells where gluten will bind to the antibody during an 211 incubation period. Any unbound gliadin is washed away and second antibody, which is 212 enzyme labeled, is added. The detector antibody binds to the gliadin during another 213 incubation period. Unbound antibody is washed away and a one step substrate is added. Color 214 develops as a result of the presence of bound-labeled antibody. Blue color indicates samples 215 containing high levels of gliadin while purple or red samples contain little or no gliadin. Color 216 is compared to negative and positive control. 
218 Statistical analysis

219 Statistical evaluation was performed by statistical software Minitab 15 (Quality Plaza, State 220 College PA, USA). We used logistic regression analysis to find out how many sections from 221 the sausage samples are necessary to examine to be able to decide with the confidence of $22295 \%$ that the wheat protein is present in the product.

\section{Results and discussion}

225 Special staining (Lugol - Calleja and PAS - Calleja staining) indicated the presence of flour 226 on the basis of different colors on the microscope slide. Lugol - Calleja staining indicated the 227 presence of flour starch particles in meat samples that were within dark purple and black 228 (Figure 1) and PAS - Calleja staining highlighted all polysaccharides in pink. The staining 229 results for meat samples were the same at different spiking levels of wheat flour. Other 230 components of meat samples were evident as various tones of green. On the other hand, 231 general staining (hematoxylin - eosin, toluidine blue) indicated flour only on the basis of their 232 typical appearance and structure in microscopic picture (Figure 2). Flour formed clusters 233 containing particles of wheat starch that looked similar to small and big lentil-like kernels. A 234 similar finding was reported by Tremlová and Štarha (2002). However, the shape of wheat 235 starch can be changed after technological processing (Aguilera and Stanley 1990).

236 Wheat protein in meat samples was histochemically identified only on the basis of 237 their typical spongy structure with openings (Figure 3). Moreover, special staining of starch 238 indicated sporadic starch granules contained in wheat protein. In contrast to flour, wheat 239 protein was not significantly differentiated based on different color from other components.

240 Only general staining with toluidine blue gave plant-origin proteins colours in different 241 shades of blue (wheat protein is light cyan) from other product components (Flint 1994). 242 Simultaneously, wheat protein in meat samples was detected by immunohistochemical 
243 methods where wheat protein was visualized as brown particles by DAB (3-3'244 Diaminobenzidine)'chromogene (Figure 4) in contrast to stained background with toluidine 245 blue (blue) or with Calleja staining (green). The staining results for meat samples and sausage 246 samples were the same at different spiking levels of wheat protein. However, this method had 247 limits in detection of wheat flour, where this staining caused only minor changes (Figure 5). 248 This phenomenon was probably caused by relatively low concentration of wheat protein in 249 wheat flour $\left(70-130 \mathrm{~g} \mathrm{~kg}^{-1}\right.$ proteins) (Keletunç and Breslauer 2003), so individual protein 250 epitopes with conjugated antibodies were too far away from each other and did not present a 251 colorful picture visible to one's eye.

Based on the above described results, meat samples containing wheat protein as well 253 as wheat flour were subjected to the combination of immunohistochemical and histochemical 254 examination specialized on starch detection. Various methods for preparation staining were 255 used to stain backgrounds after immunohistochemical processing. Combinations used were 256 PAS - Calleja, Lugol - Calleja, and, for stronger contrast between wheat protein highlighted 257 by DAB chromogene and other components, also Lugol - toluidine blue and PAS - toluidine 258 blue. From the above combinations, PAS - Calleja staining (Figure 6) provided the largest 259 color differences between the monitored components. Combinations with Lugol solution 260 staining resulted in weaker color contrast between starch and wheat protein and partially in 261 interference of individual stains.

Immunohistochemical detection of meat samples was compared to results achieved by 263 reference ELISA method. The ELISA method reliably detected wheat protein concentrations 264 from $4 \mathrm{~g} \mathrm{~kg}^{-1}$ while immunohistochemical method detected wheat protein concentrations from $2651 \mathrm{~g} \mathrm{~kg}^{-1}$ (Table 2). Generally acknowledged requirement on detection limit for allergen is a 266 value of 1 to $100 \mathrm{mg} \mathrm{kg}^{-1}$ of allergens in food products, depending on allergen type, possibly 267 depending on analytical possibilities (Koppelman and Hefle 2006). Upper limit of this range 
268 is identical with upper limit of acceptable amount of gluten in gluten-free food products as 269 stated by Commission Regulation (EC) No. 41/2009 concerning composition and labeling of 270 foodstuffs suitable for people intolerant to gluten. It establishes that retail-sale form of food 271 products for people intolerant to gluten must not contain more than $20 \mathrm{mg} \mathrm{kg}^{-1}$ of gluten in 272 case they do not include any constituents from wheat or other types of Triticum, or more than $273100 \mathrm{mg} \mathrm{kg}^{-1}$ of gluten in case constituents from wheat or other types of Triticum were used at 274 their production.

275 Detection of wheat protein by ELISA method, commercially available ALERT gliadin 276 screening test, and immunohistochemical procedure with toluidine blue staining in sausage 277 samples is shown in Table 3. The only method with negative detection of samples with wheat 278 protein was the ELISA method (Table 2 and 3). We suppose that this negative detection was 279 possibly caused by decreased sensitivity of detection method (detection limit $4-5 \mathrm{~g} \mathrm{~kg}^{-1}$ ), or 280 possibly, in cooked products, by worsened availability of antigen after technological 281 processing of the product. The only method which met the commonly acknowledged 282 detection limit was the ALERT gliadin screening test. Producer of this test claims ability to 283 detect gliadin already from $10 \mathrm{mg} \mathrm{kg}^{-1}\left(20 \mathrm{mg} \mathrm{kg}^{-1}\right.$ of gluten) in this test, which is confirmed 284 also by results of this study. However, in our control sausage samples of dry sausage and raw 285 sausage without any wheat protein addition this test showed false positive reaction. This 286 might have been caused by cross-contamination of samples during preparation for 287 examination, which included sample grinding (in one machine). Including sample 288 preparation, immunohistochemical procedure showed results in 5 days at the soonest, while 289 ELISA detection method in two days, and ALERT gliadin test within one day.

290 Immunohistochemical method seems to be sensitive and reliable method that contains 291 current possibilities of food microscopy - detection of food components, quality detection, 292 and arrangement of individual food components, adulteration of foodstuffs, risk components 
293 detection in food products, and possible quantification of food components (Heertje and 294 Leunis 1997). Microscopy represents an effective and in many cases irreplaceable instrument 295 for achieving necessary information. Unlike immunochemical methods that can mostly detect 297 components within one analysis (Heertje at al. 1997).

Our study was also focused on optimization of immunohistochemical procedure, 299 which was performed in sausage samples of cooked sausage. We found out how many 300 sections from the sausage sample are necessary to examine to be able to decide with the 301 confidence of $95 \%$ that the wheat protein is present in the product. If the test of dependence 302 of wheat protein concentration with respect to the probability of detection (using logistic 303 regression) is made, wheat protein concentration will be significant at significance level of 304 0.05. If the information, that there are 7 types of samples, is added into model, also the factor 305 "sample type" will be significant at significance level of 0.05 . It is a problem because we 306 would make a model where the wheat protein detection is examined with respect to the 307 concentration and sample type. But we do not have enough data for this model. We focused 308 on the sample with the worst detection ratio which was the homogenate of cooked sausage 309 with $1 \mathrm{~g} \mathrm{~kg}^{-1}$ addition of wheat protein (Table 4). The point estimate for probability of wheat 310 protein detection was $63 / 75=0.84$. If only one section was made, the probability of wheat 311 protein detection was $\mathrm{p}=0.753692$ using one-sided interval estimate with confidence $95 \%$. If

312 two sections were made, the probability of wheat protein detection was $1-(1-p)^{2}=0.9393$, 313 which was still less than 0.95 . If three sections were made, the probability of wheat protein 314 detection was $1-(1-p)^{3}=0.9850$, which was greater than 0.95 . Therefore, three sections 315 were sufficient for at least one wheat protein detection at concentration of $1 \mathrm{~g} \mathrm{~kg}^{-1}$ (and 316 greater) with confidence level greater than $95 \%$. The calculated minimum number of 317 examined sections necessary for reliable detection then needs to be increased by losses caused 
318 by harms to sections during processing (e.g. section drifting away while staining), which were

$3196.1 \%$. The optimization also included shortening the time of immunohistochemical method.

320 In order to decrease time consumption, this procedure was shorted to one day. The main 321 change was especially in incubation with an polyclonal anti-wheat antibody that was for 1 322 hour at room temperature instead of $12 \mathrm{~h}$ at $8^{\circ} \mathrm{C}$.

323

324 Conclusion

325 ALERT gliadin screening test was more sensitive and faster than other tested methods. 326 Indirect competitive ELISA developed in our laboratory was used as the reference method, 327 but it was not sensitive enough with regard to upper limit of acceptable amount of gluten in 328 gluten-free food products as stated by Commission Regulation (EC) No. 41/2009. A 329 immunohistochemical procedure, eventually complemented by special staining of starch, 330 seems to be a suitable diagnostic method and it was more sensitive than ELISA, however, it 331 was time-consuming. Therefore, we shortened this procedure to one day only. In addition, 332 three samples were sufficient for at least the detection of one wheat protein at a concentration 333 of $1 \mathrm{~g} \mathrm{~kg}^{-1}$ (and greater) with confidence level greater than $95 \%$.

335 Acknowledgements

336 This work was supported by project NAZV No. 1B53004, research intention of Veterinary 337 aspects of foodstuffs safety and quality (MŠMT No. 6215712402) and project IGA VFU 2009 338 No. 206/2009/VFU.

$340 \quad$ References

341 Asensio L, González I,García T, Martín R. 2008. Determination of food authenticity by 342 enzyme-linked immunosorbent assay (ELISA). Food Control 19(1): 1 - 8. 
343 Aguilera JM, Stanley DW. 1990. Microstructural principles of food processing \& 344 engineering. New York: Elsevier Science Publishers LTD.

345 Bancroft JD, Cook HC. 1994. Manual of histochemical techniques and their diagnostic 346 application. Churchill Livingstone. pp. 73, 210, 242.

Belloque J, García MC, Torre M, Marina ML. 2002. Analysis of soybean proteins in meat products: a review. CRC. Critical Reviews in Food Science Nutrition 42(5): 507 - 532.

Calleja C. 1897. Método de tripla coloración noc el karmín litinado y el picrocarmín de indigo. Revista Trimestral Micrográfia II: 100 - 1004.

Ciclitira PJ, Ellis HJ, Lundin KEA. 2005. Gluten-free diet-what is toxic? Best Practice \& Research Clinical Gastroenterology 19(3): 359 - 371.

Commission Regulation (ES) No. 41/2009 on 20. January 2009 concerning composition and labeling of foodstuffs suitable for people intolerant to gluten. Official Journal of the European Union L16, 21/01/2009.

Day L, Augustin MA, Batey IL, Wrigley CW. 2006. Wheat-gluten uses and industry needs. Trends in Food Science \& Technology 17(2): 82 - 90.

Flint O. 1994. Food Microscopy: a manual of practical methods, using optical microscopy. Microscopy handbooks 30. Oxford: BIOS Scientific Publishers Limited. pp. 27 - 28.

Heertje I, Leunis M. 1997. Measurement of Shape and Size of Fat Crystals by Electron Microscopy. Lebensmittel-Wissenschaft und-Technologie 30(2): 141 - 146.

Hischenhuber C,Crevel R, Jarry B, Mäkis M, Moneret-Vautrin DA, Romano A, Troncone R, Ward R. 2005. Review article: safe amounts of gluten for patients with wheat allergy or coeliac disease. Alimentary Pharmacology \& Therapeutics 23: 559 - 575.

Keletunç G, Breslauer KJ. 2003. Characterization of Cereals and Flours, Properties, Analysis, and Applications. New York: Marcel Dekker, Inc. 
367 Koppelman SJ, Hafle SL. 2006. Detecting allergens in food. New York: Woodhead $368 \quad$ Publishing Limited Cambridge England.

369 Minitab User's Guide 2. 2000. Data Analysis and Quality tools. USA.

370 Moriyama T, Machidori M, Ozasa S, Maebuchi M, Urade R, Takahashi K, Ogawa T, 371 Maruyama N. 2005. A novel enzyme-linked immunosorbent assay for quantification of 372 soybean beta-conglycinin, a major soybean storage protein, in soybean and soybean 373 food products. Journal of Nutritional Science and Vitaminology 51(1): $34-39$.

374 Pickering K, Griffin M, Smethurst P, Hargin KD, Stewart CA. 1995. Investigation of methods 375 to detect mechanically recovered meat in meat products - IV: Immunology. Meat $376 \quad$ Science $40(3): 327-336$.

377 Poms RE, Klein L, Anklam E. 2004. Methods for allergen analysis in food: a review. Food $378 \quad$ Additives and Contaminants 21(1): $1-31$.

379 Pospiech M, Tremlová B, Renčová E, Randulová Z. 2009. Immunohistochemical Detection of 380 Soya Protein - Optimisation and Verification of the Method. Czech Journal Food $381 \quad$ Science 27(1): $11-19$.

382 Protocols. 1989. Amtliche Sammlung von Untersuchungsverfahren nach $\S 35$ LMBG, 383 Bestimmung der geweblichen Zusammensetzung von Fleisch, Fleischerzeugnissen und 384 Wurstwaren L 06.00.13, Beuth Verlag Berlin und Köln.

385 Protocols. 1997. Analysenvorschrift. Färbung nach Bauer-Calleja. $386 \quad$ Veterinäruntersuchungsanstalt Detmold.

387 Rencova E., Svoboda I., Necidova L. 2000. Identification by ELISA of poultry, horse, 388 kangaroo, and rat muscle specific proteins in heat-processed products.Vet. Med.- Czech $389 \quad 45: 353-356$.

390 Rencova E., Tremlova B. 2009. ELISA for detection of soya proteins in meat products. Acta $391 \quad$ Veterinaria Brno 78: 667-671. 
392 Sicherer SH, Sampson HA. 1999. Food hypersensitivity and atopic dermatitis: 393 Pathophysiology, epidemiology, diagnosis, and management. Journal of Allergy and $394 \quad$ Clinical Immunology 104(3): $114-122$.

395 Stern M, Ciclitira PJ, van Eckert R, Feighery C, Janssen FW, Méndez E, Mothes T, Troncone 396 R, Wiesner H. 2001. Analysis and clinical effects of gluten in coeliac disease. European $397 \quad$ Journal of Gastroenterology \& Hepatology 13(6): 741 - 747.

398 Šalplachta J, Allmaier G, Chmelík J. 2005. Proteomic identification of gluten proteins. $399 \quad$ Chemické Listy 99(12): 967 - 971.

400 Šedivý V. 1998. Spotřební normy pro masné výrobky. Tábor : OSSIS - Ing. Václav Šedivý. 401 Thompson T, Méndez E. 2008. Commercial Assays to Assess Gluten Content of Gluten-Free 402 Foods: Why They Are Not Created Equal. Journal of the American Dietetic Association $403 \quad 108(10): 1682-1687$.

404 Tremlová B, Štarha P. 2002. Die Bewertung der histologischen Methoden zum Nachweis der 405 pflanzlichen Bestandteile in den Fleischerzeugnissen mit Rücksicht auf die Anwendumg 406 sed Bild-Analyse-Systems In 43. Arbeitstagung des Arbeitsgebietes 407 „Lebenmittelhygiene“. Garmisch-Parkenkirchen, 838- 842.

408 Vaňha J, Kvasnička F, Prokorátorová V. 2002. Detekce sójových bílkovín v masných $409 \quad$ výrobcích. Maso 13(5): 36 - 39.

410 Zeltner D, Glomb MA, Maede D. 2009. Real-time PCR systems for the detection of the 411 gluten-containing cereals wheat, spelt, kamut, rye, barley and oat. European Food $412 \quad$ Research and Technology, 228: $321-330$.

414 "Table 1"

415 "Table 2"

416 "Table 3" 
417 "Table 4"

418

419 "Figure 1"

420 "Figure 2"

421 "Figure 3"

422 "Figure 4"

423 "Figure 5"

424 "Figure 6" 


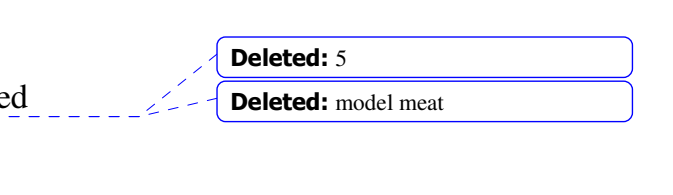
2 sausage.

\begin{tabular}{|c|c|c|c|c|c|}
\hline $\begin{array}{c}\text { Wheat protein } \\
\text { additive }\end{array}$ & Sample & $\begin{array}{l}\text { Number of } \\
\text { sections with } \\
\text { positive } \\
\text { result }\end{array}$ & $\begin{array}{c}\text { Number of } \\
\text { sections with } \\
\text { negative } \\
\text { result }\end{array}$ & $\begin{array}{l}\text { Number of } \\
\text { examined } \\
\text { sections }\end{array}$ & $\begin{array}{c}\text { Losses } \\
\text { during } \\
\text { processing }\end{array}$ \\
\hline & $\mathrm{ZO}$ & 74 & 0 & 74 & 1 \\
\hline & $\mathrm{PO}$ & 71 & 4 & 75 & 0 \\
\hline & $\mathrm{KO}$ & 68 & 3 & 71 & 4 \\
\hline \multirow[t]{7}{*}{$1 \mathrm{~g} \mathrm{~kg}^{-1}$} & $\mathrm{ZS}$ & 73 & 1 & 74 & 1 \\
\hline & PS & 64 & 5 & 69 & 6 \\
\hline & $\mathrm{KS}$ & 64 & 9 & 73 & 2 \\
\hline & $\mathrm{HO}$ & 63 & 12 & 75 & 0 \\
\hline & $\mathrm{ZO}$ & 74 & 0 & 74 & 1 \\
\hline & $\mathrm{PO}$ & 72 & 0 & 72 & 3 \\
\hline & $\mathrm{KO}$ & 71 & 2 & 73 & 2 \\
\hline \multirow[t]{4}{*}{$5 \mathrm{~g} \mathrm{~kg}^{-1}$} & $\mathrm{ZS}$ & 73 & 0 & 73 & 2 \\
\hline & PS & 75 & 0 & 75 & 0 \\
\hline & $\mathrm{KS}$ & 75 & 0 & 75 & 0 \\
\hline & $\mathrm{HO}$ & 72 & 3 & 75 & 0 \\
\hline \multirow[t]{5}{*}{$15 \mathrm{~g} \mathrm{~kg}^{-1}$} & $\mathrm{ZO}$ & 70 & 0 & 70 & 5 \\
\hline & $\mathrm{PO}$ & 72 & 0 & 72 & 3 \\
\hline & $\mathrm{KO}$ & 72 & 0 & 72 & 3 \\
\hline & $\mathrm{ZS}$ & 69 & 3 & 72 & 3 \\
\hline & PS & 72 & 0 & 72 & 3 \\
\hline
\end{tabular}




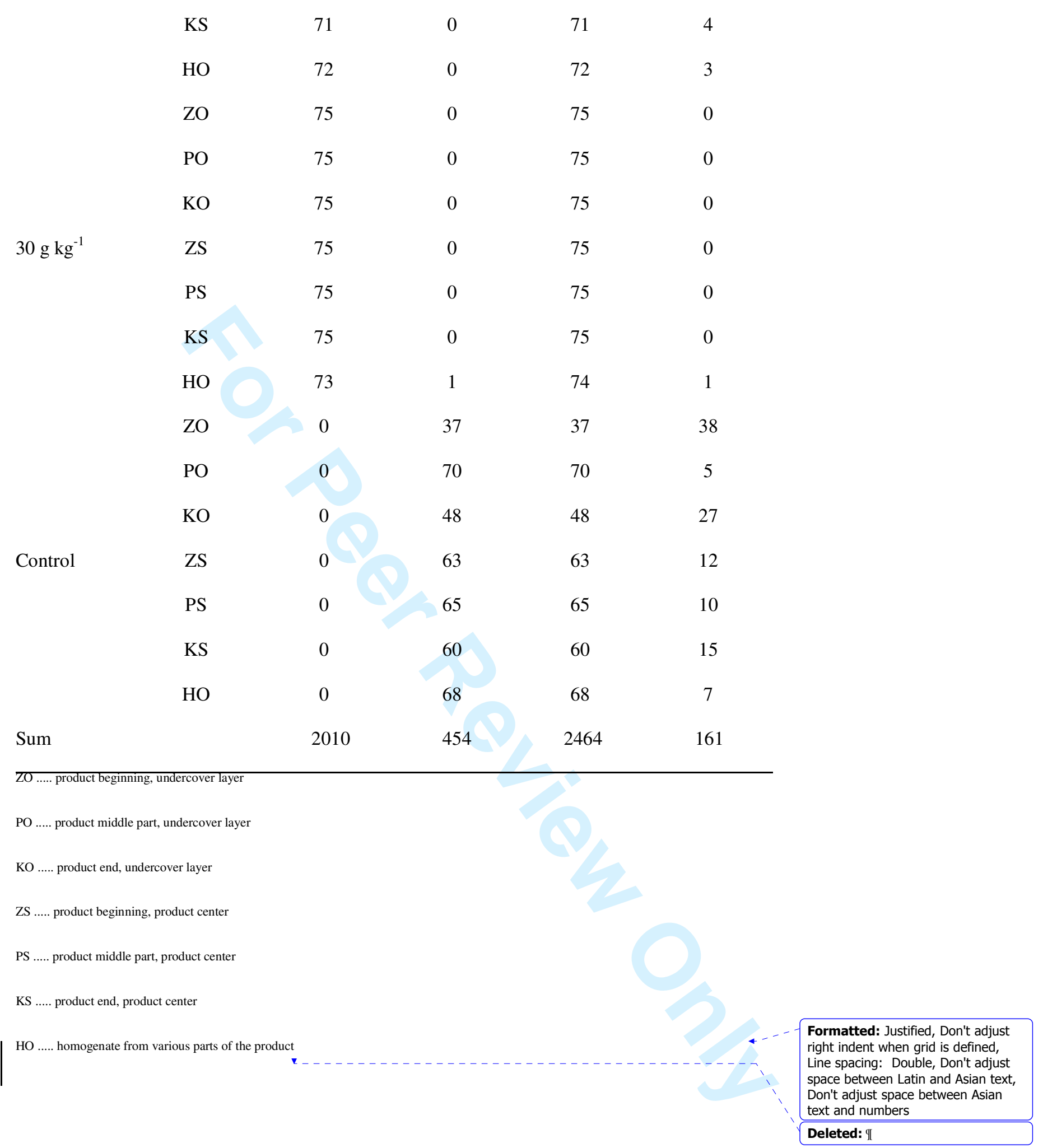




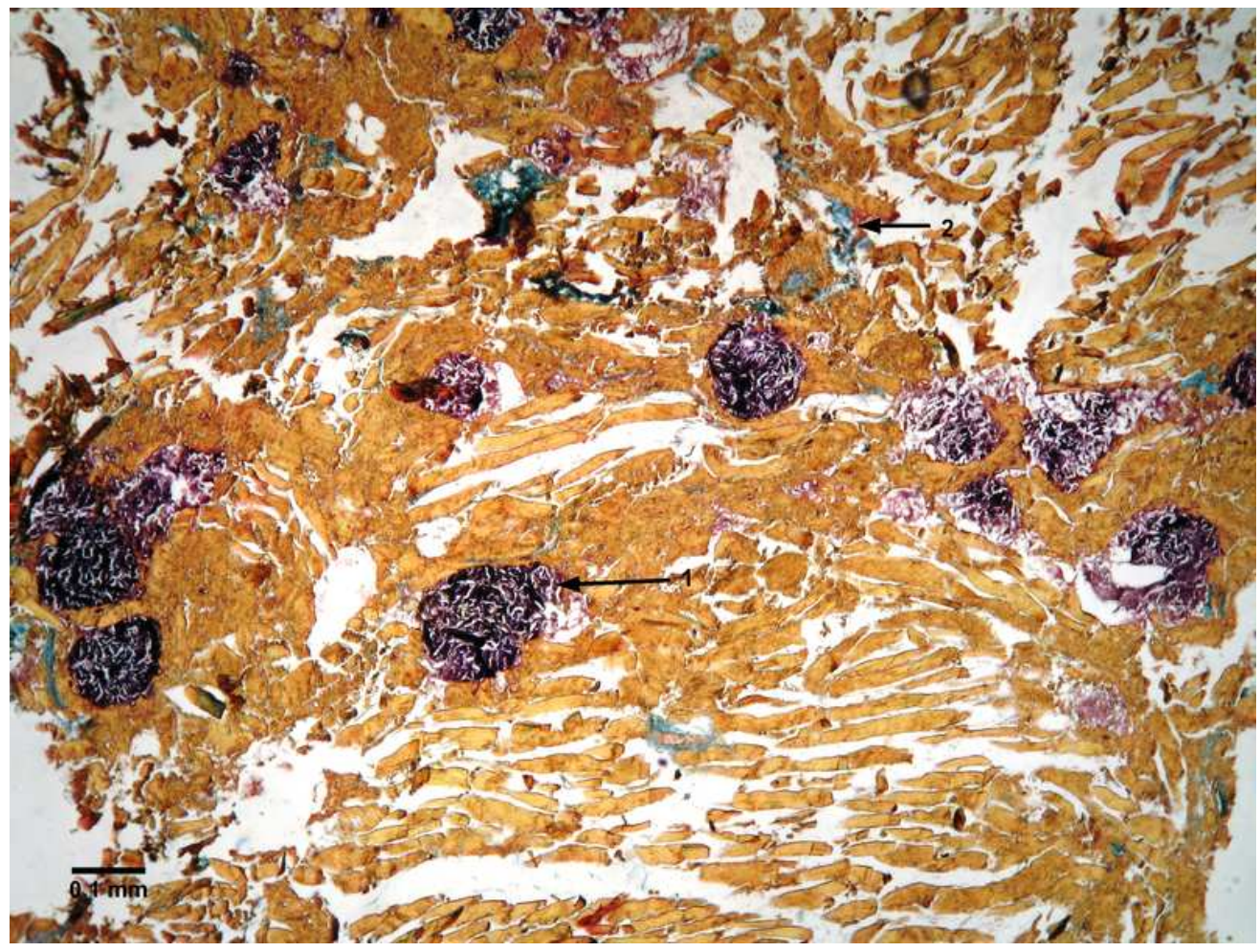

Meat sample - meat with wheat flour, Lugol - Calleja staining, examined at 40x, (1) wheat flour, (2) collagen.

$67 \times 50 \mathrm{~mm}(300 \times 300 \mathrm{DPI})$ 


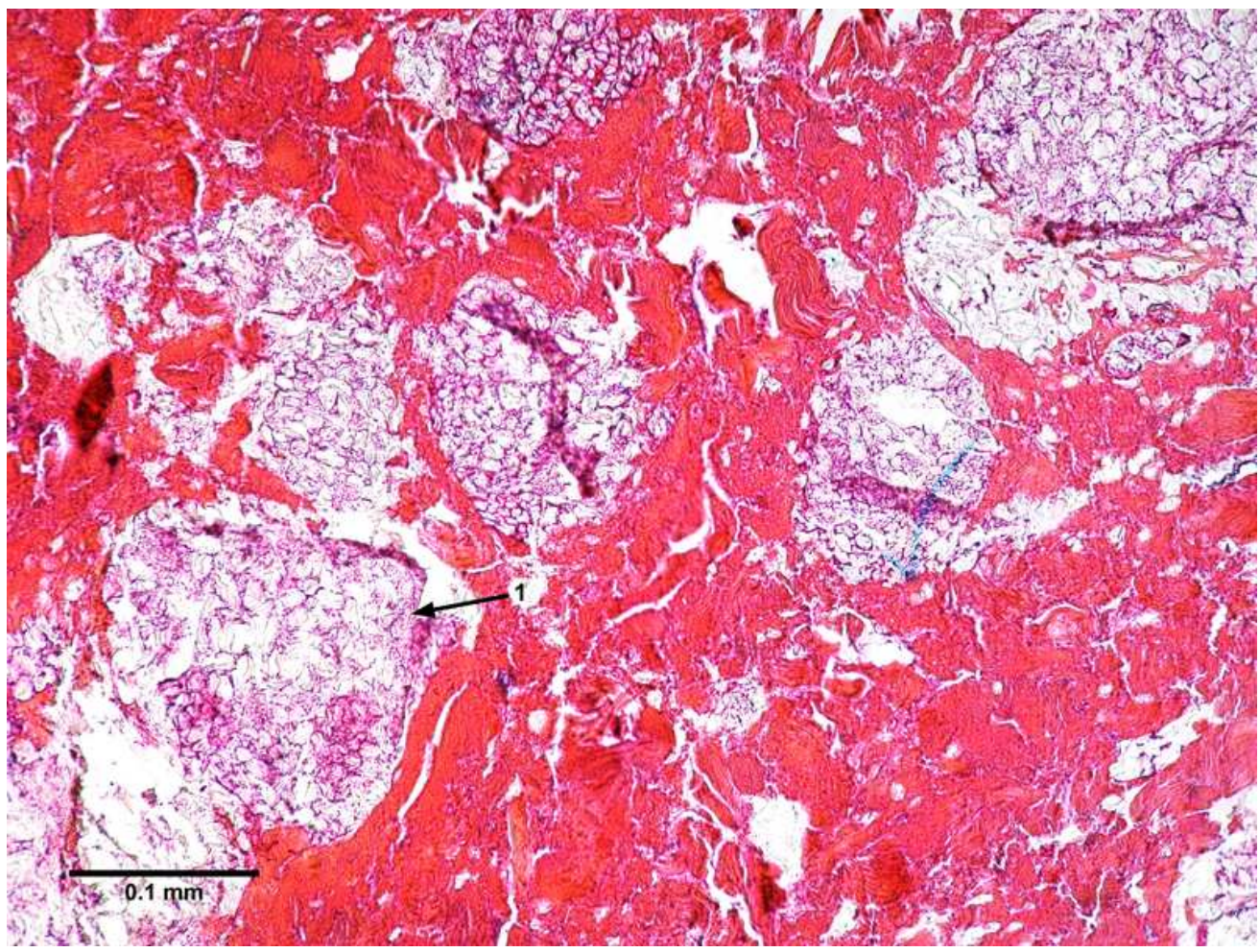
Meat sample - meat with wheat flour, Hematoxylin - Eosin staining, examined at 100x, (1) wheat flour.
$67 \times 50 \mathrm{~mm}(300 \times 300$ DPI $)$




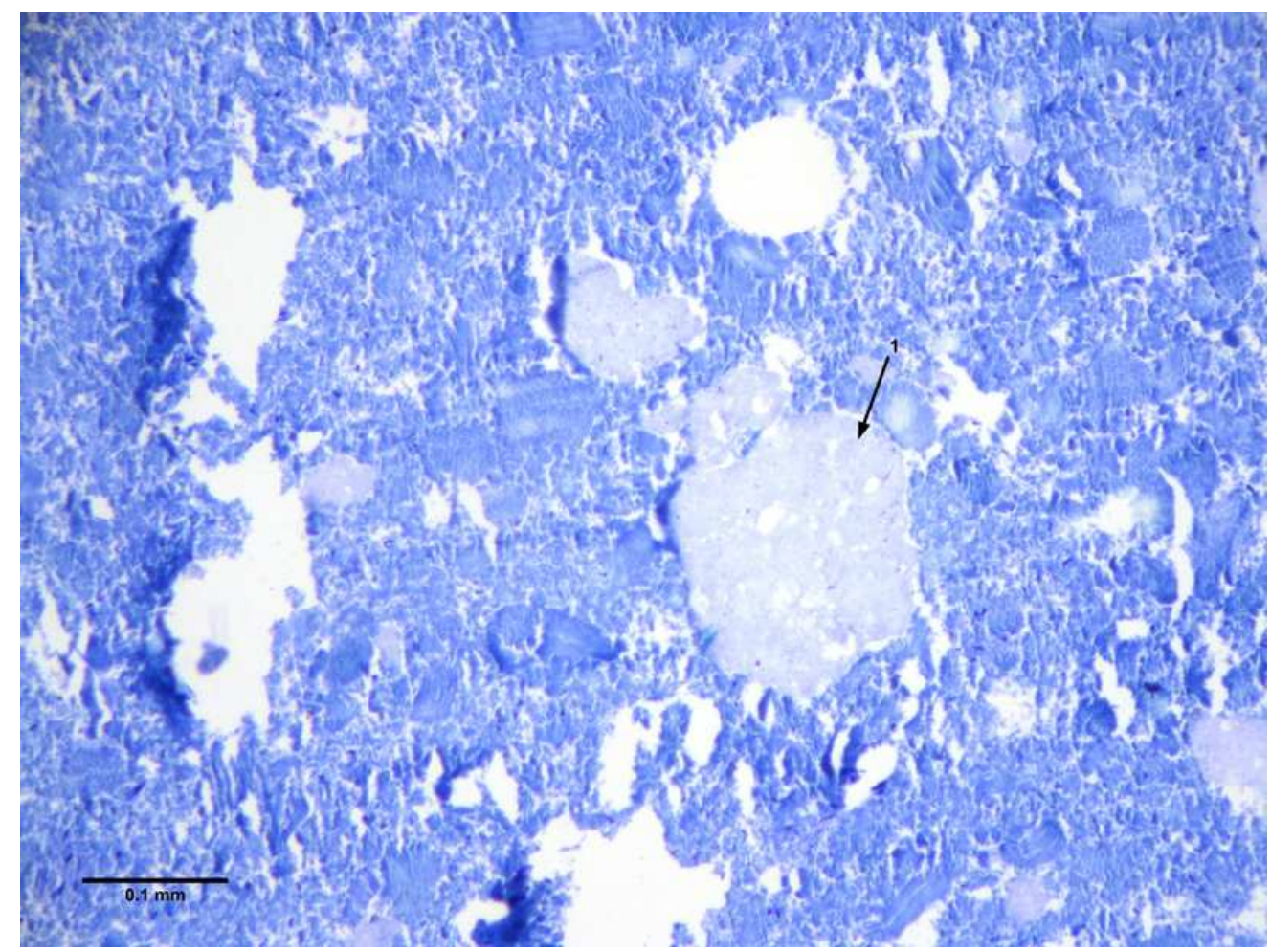

Meat sample - meat with wheat protein, toluidine blue staining, examined at 100x, (1) wheat protein.

$67 \times 50 \mathrm{~mm}(300 \times 300 \mathrm{DPI})$ 


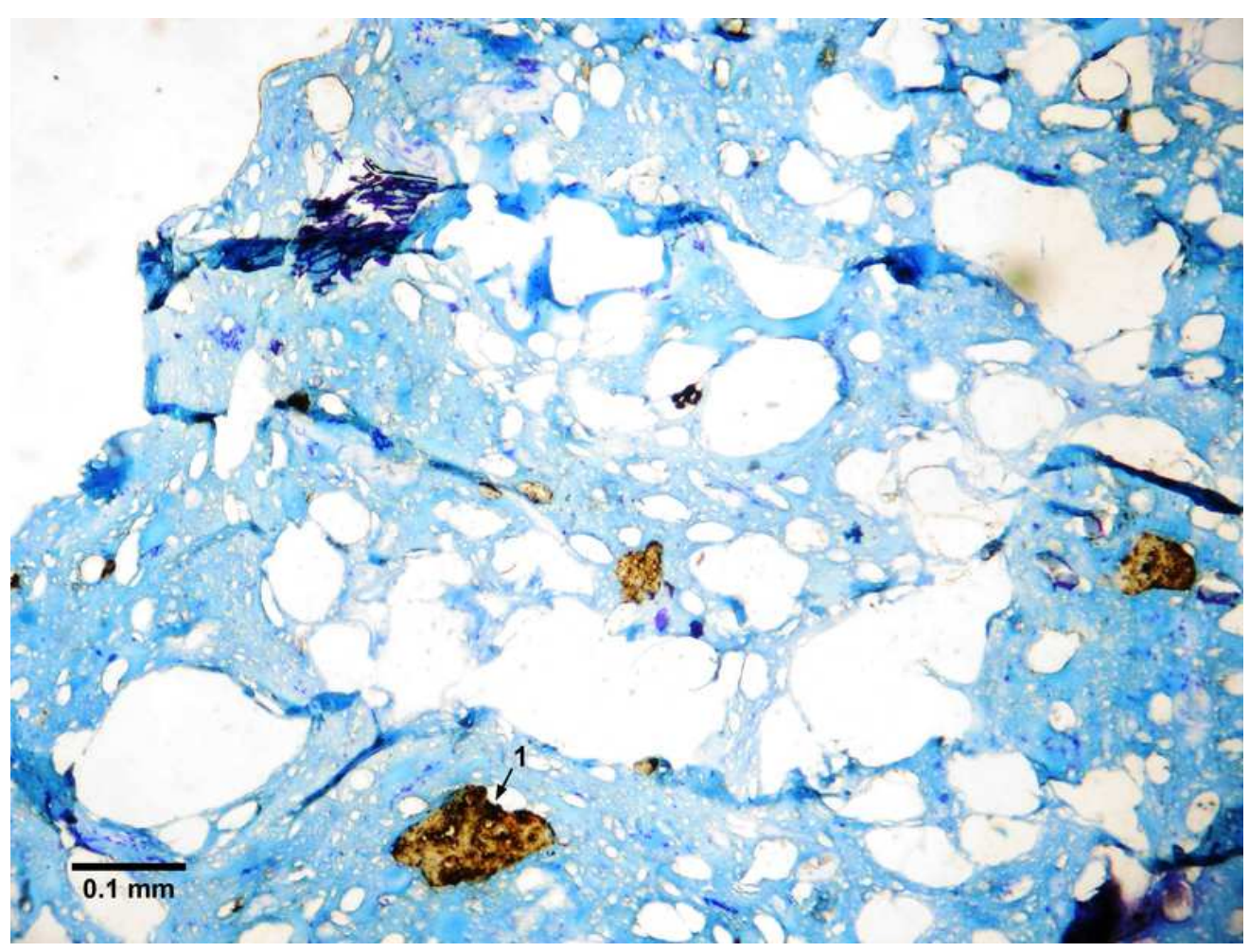

Sausage sample - cooked sausage with wheat protein, immunohistochemical method, highlighted by $D A B$ chromogene, toluidine blue staining, examined at $40 x,(1)$ wheat protein. $67 \times 50 \mathrm{~mm}$ (300 x 300 DPI) 


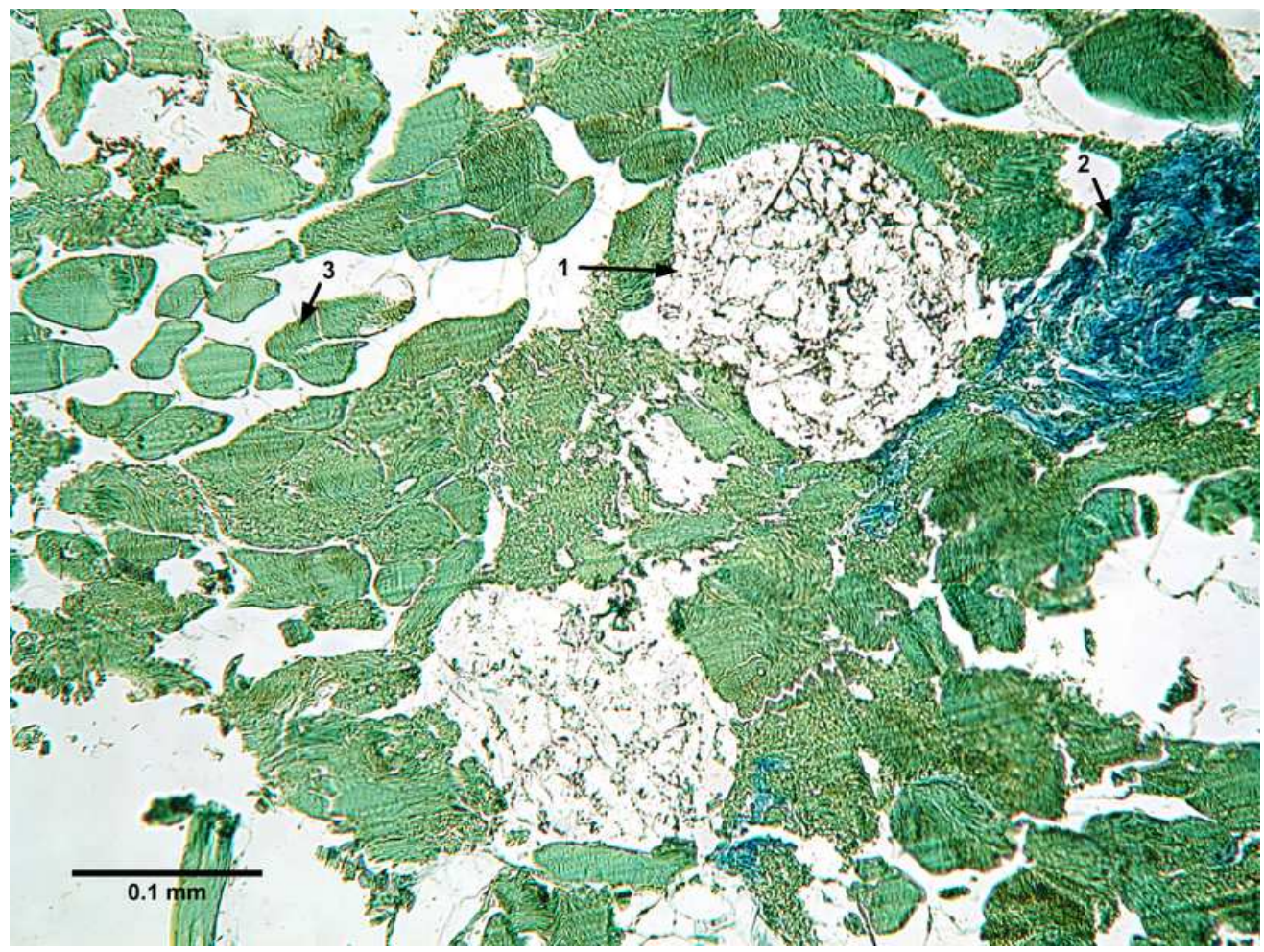

Meat sample - meat with wheat flour, immunohistochemical method, highlighted by DAB chromogene, staining according to Calleja, examined at 100x, (1) flour, (2) collagen, (3) muscle tissue.

$67 \times 50 \mathrm{~mm}(300 \times 300$ DPI $)$ 


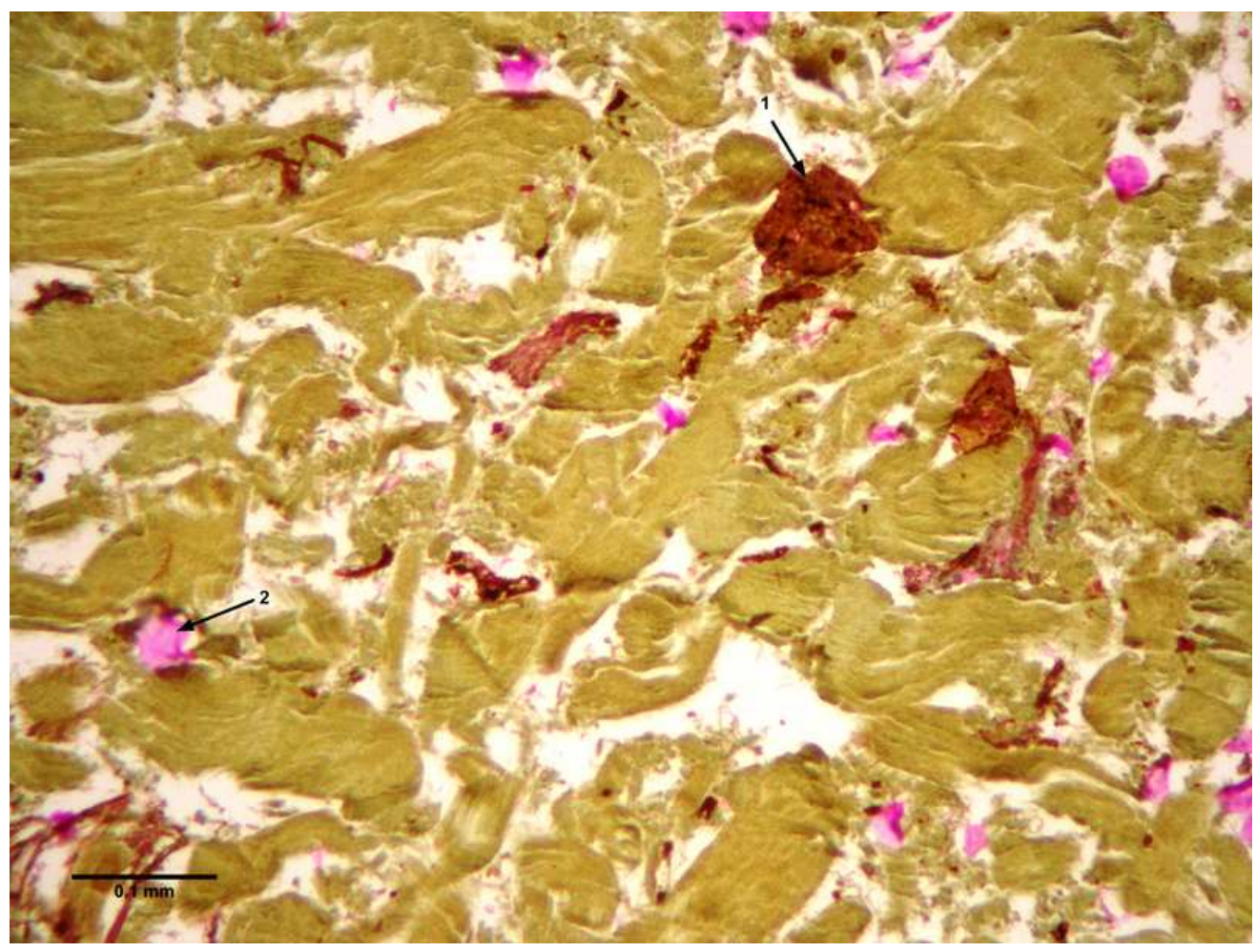

Meat sample - meat with wheat flour and wheat protein, immunohistochemical method, highlighted by DAB chromogene, PAS -Callea staining, examined at 40x, (1) wheat protein, (2) wheat flour. $67 \times 50 \mathrm{~mm}(300 \times 300 \mathrm{DPI})$ 
Table 1. Summary of methods used for examination of sample groups.

\begin{tabular}{|c|c|c|c|}
\hline \multirow{2}{*}{ Sample } & \multicolumn{3}{|c|}{ Methods } \\
\hline & Histochemistry & Immunochemistry & Immunohistochemistry \\
\hline \multirow{8}{*}{$\begin{array}{l}\text { Meat sample with } \\
\text { wheat protein }\end{array}$} & general staining & ELISA & + Calleja \\
\hline & (hematoxylin - eosin, & & + toluidine blue \\
\hline & toluidine blue) & & \\
\hline & special staining & & \\
\hline & (Lugol-Calleja, & & \\
\hline & PAS - Calleja) & & \\
\hline & general staining & - & + Calleja \\
\hline & (hematoxylin - eosin, & & + toluidine blue \\
\hline \multirow{4}{*}{ Meat sample with flour } & toluidine blue) & & \\
\hline & special staining & & \\
\hline & (Lugol - Calleja, & & \\
\hline & PAS - Calleja) & & \\
\hline \multirow[t]{4}{*}{ Meat sample with flour } & - & 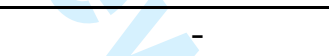 & + PAS - Calleja \\
\hline & & & + PAS - toluidine blue \\
\hline & & & + Lugol-Calleja \\
\hline & & & + Lugol - toluidine blue \\
\hline \multirow[t]{2}{*}{ Sausage samples } & - & ELISA & + toluidine blue \\
\hline & & ALERT test & \\
\hline
\end{tabular}


Table 2. Comparison of ELISA method with immunohistochemical examination of meat samples.

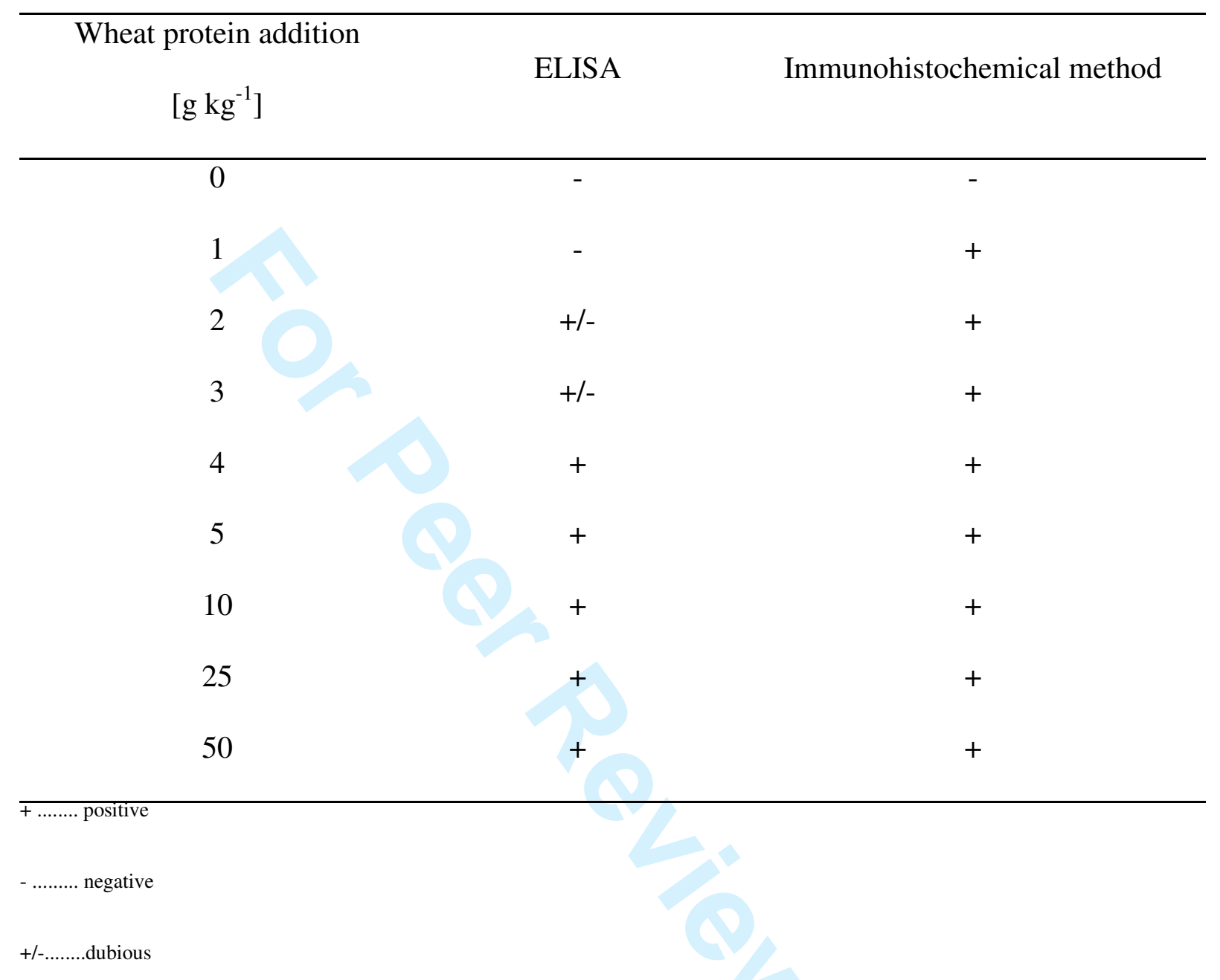


Table 3. Comparison of ELISA method, ALERT gliadin screening test and immunohistochemical examination of sausage samples.

\begin{tabular}{|c|c|c|c|c|}
\hline Product & $\begin{array}{l}\text { Wheat protein } \\
\text { addition }\left[\mathrm{g} \mathrm{kg}^{-1}\right]\end{array}$ & ELISA & $\begin{array}{l}\text { ALERT gliadin } \\
\text { screening test }\end{array}$ & $\begin{array}{c}\text { Immunohistochemical } \\
\text { method }\end{array}$ \\
\hline \multirow{5}{*}{ Cooked sausage } & 0 & - & - & - \\
\hline & 1 & - & + & + \\
\hline & 5 & + & + & + \\
\hline & 15 & + & + & + \\
\hline & 30 & + & + & + \\
\hline \multirow{5}{*}{ Dry sausage } & 0 & - & + & - \\
\hline & 1 & - & + & + \\
\hline & 5 & + & + & + \\
\hline & 15 & + & + & + \\
\hline & 30 & + & + & + \\
\hline \multirow{5}{*}{ Raw sausage } & 0 & - & + & - \\
\hline & 1 & + & + & + \\
\hline & 5 & + & + & + \\
\hline & 15 & + & + & + \\
\hline & 30 & + & + & + \\
\hline \multirow{5}{*}{ Fermented } & 0 & + & - & - \\
\hline & 1 & + & + & + \\
\hline & 5 & + & + & + \\
\hline & 15 & + & + & + \\
\hline & 30 & + & + & + \\
\hline
\end{tabular}



33 35 9 41 4 6 . 
1 Table 4. Summary of immunohistochemical examination of sausage samples of cooked

2 sausage.

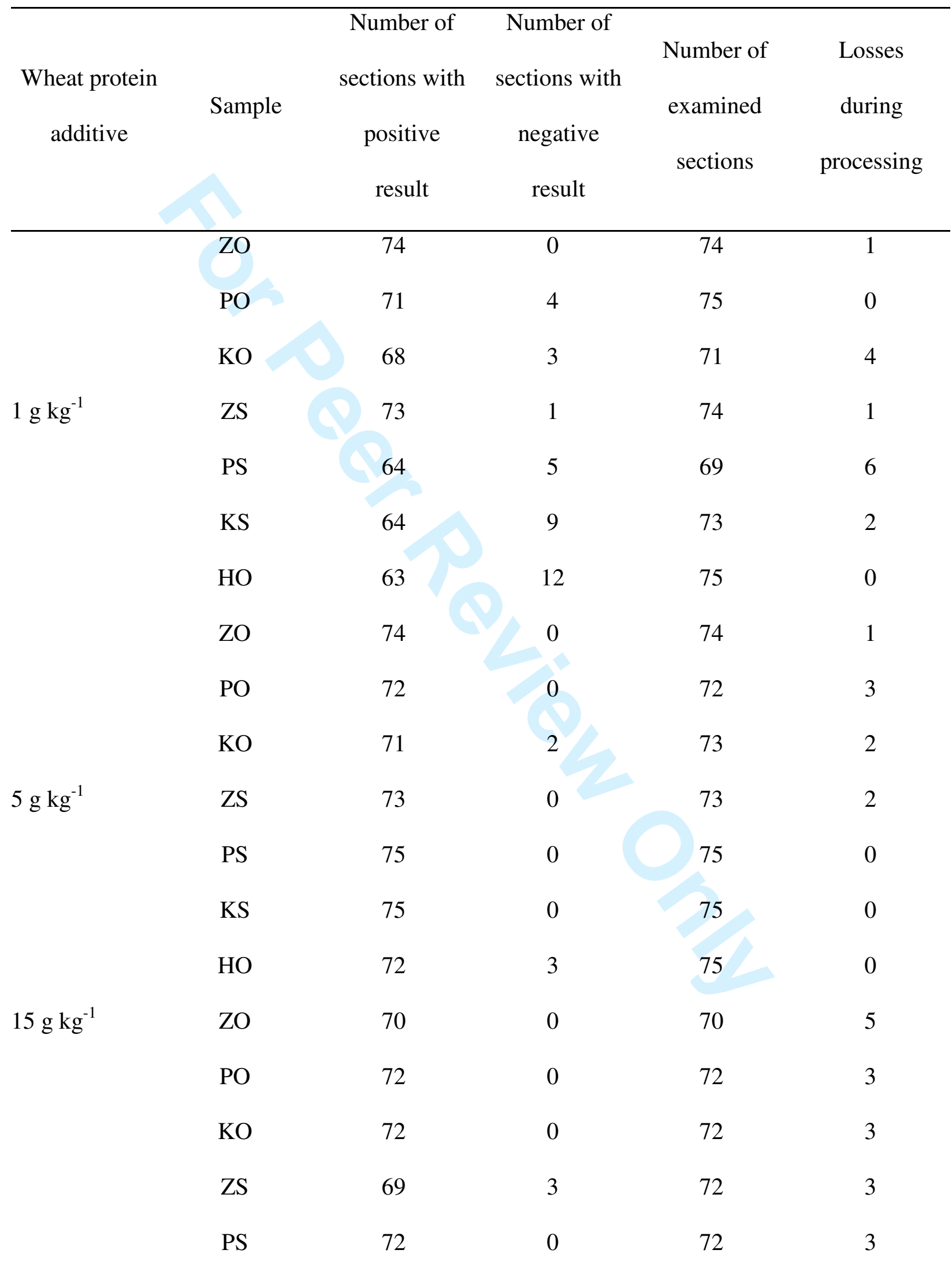




\begin{tabular}{|c|c|c|c|c|c|}
\hline & KS & 71 & 0 & 71 & 4 \\
\hline & $\mathrm{HO}$ & 72 & 0 & 72 & 3 \\
\hline & $\mathrm{ZO}$ & 75 & 0 & 75 & 0 \\
\hline & $\mathrm{PO}$ & 75 & 0 & 75 & 0 \\
\hline & $\mathrm{KO}$ & 75 & 0 & 75 & 0 \\
\hline $30 \mathrm{~g} \mathrm{~kg}^{-1}$ & $\mathrm{ZS}$ & 75 & 0 & 75 & 0 \\
\hline & PS & 75 & 0 & 75 & 0 \\
\hline & $\mathrm{KS}$ & 75 & 0 & 75 & 0 \\
\hline & $\mathrm{HO}$ & 73 & 1 & 74 & 1 \\
\hline & $\mathrm{ZO}$ & 0 & 37 & 37 & 38 \\
\hline & $\mathrm{PO}$ & 0 & 70 & 70 & 5 \\
\hline & $\mathrm{KO}$ & 0 & 48 & 48 & 27 \\
\hline Control & ZS & 0 & 63 & 63 & 12 \\
\hline & PS & 0 & 65 & 65 & 10 \\
\hline & $\mathrm{KS}$ & 0 & 60 & 60 & 15 \\
\hline & $\mathrm{HO}$ & 0 & 68 & 68 & 7 \\
\hline Sum & & 2010 & 454 & 2464 & 161 \\
\hline
\end{tabular}

3

$4 \quad$ PO ..... product middle part, undercover layer

$5 \quad \mathrm{KO} \ldots .$. product end, undercover layer

6 ZS ..... product beginning, product center

7 PS ..... product middle part, product center

$8 \quad$ KS ..... product end, product center

9 HO ..... homogenate from various parts of the product 